\title{
COMMENT
}

\section{A Taxonomy of Privacy: Repose, Sanctuary, and Intimate Decision}

In this Comment the author suggests that the right of privacy in fact encompasses three separate and distinct rights. Unless the three interests are viewed discretely and analyzed within the appropriate framework, privacy becomes a catchall phrase, protecting too little because it protests too much. The Comment subdivides privacy into its three components-repose, sanctuary, and intimate decisionand provides a guide to aid in proper classification and analysis of privacy claims.

In his time-honored dissent in Olmstead $v$. United States ${ }^{1}$ Justice Brandeis called the right to be let alone "the most comprehensive of rights and the right most valued by civilized men."2 Brandeis' views on wiretappimg in Olmstead have since been vindicated, ${ }^{3}$ but his defense of human autonomy has had even greater effect. The right to privacy, if not the right most valued by civilized persons, has certainly become a right highly valued by contemporary advocates fashioning pleadings in pursuit of relief for their clients. Even a partial listing of cases decided in the past 5 years in which one of the participants has invoked the concept of privacy would cover a wide spectrum of interests. The list would include such questions as whether a city inay refuse to allow political advertising on its buses, ${ }^{4}$ whether a father has the riglit to order that life support systems be disconnected from his comatose daughter, ${ }^{5}$ whether a state may prohibit sodoiny between consenting adults in private, ${ }^{6}$ whether a city can restrict the number of unrelated imdividuals living in one house, ${ }^{7}$ and whether evidence is admissible if it results froin a search founded upon a warrant granted because of the positive reaction of marijuana-sniffing dogs to a trailer parked in a public space. ${ }^{8}$

1. 277 U.S. 438 (1928).

2. Id. at 478.

3. See text accompanying notes 73-75.

4. Lehman v. Shaker Heights, 418 U.S. 298 (1974).

5. In re Quinlan, 70 N.J. 10, 355 A.2d 647 (1976).

6. Doe v. Commonwealth's Att'y, 403 F. Supp. 1199 (E.D. Va. 1975).

7. Belle Terre v. Boraas, 416 U.S. 1 (1974).

8. United States v. Solis, 536 F.2d 880 (9th Cir. 1976). 
That "privacy" was at issue in each of these cases should not obscure the important differences among them. Different interests, which compel different treatment by court and counsel, have nonetheless been included under the common rubric of "privacy." In soine situations the privacy interest has been given constitutional protection; im others it has been given hittle protection of any kind. The United States Supreme Court has rendered a variety of decisions, covering the entire spectrum of degrees of protection. To construct a consistent synthesis of those holdïgs favoring privacy is difficult. Justice Rehnquist emphasized the difficulty of the task and characterized the Court's past holdings on privacy as either involving unreasonable searches or "defying categorical description." The inescapable implication is that a right without description is a right without protection.

Privacy analysis has suffered considerable confusion for several reasons. There is little agreement about the source of the right. More importantly, cases are frequently lumped together in groups according to some legal conclusion or catch phrase rather than according to the primary facts that give rise to the conflict. ${ }^{10}$ Almost all privacy issues, for instance, are related in some fashion to the fourth amendment, but it serves little purpose to consider that relationship without first determinimg what interest is asserted and how that interest can be protected, if at all. This Cominent therefore analyzes past cases on the basis of primary facts rather than ultimate conclusions. Such a presentation rests upon the theory that incremental differences between the fact situations of the relevant cases provide data points through which a doctrinal hine can be drawn and extrapolated to help make predictions about future privacy cases. The catalogumg of cases within each class is an attempt to show the loci of those points, starting with the most basic fact situation and proceeding to increasmgly variegated combimations. As such, the inethod is as old as the common law itself. Yet this simple approach has been ignored in privacy law.

The thesis of this Cominent is that cases involving "privacy" can be grouped in three classes: the privacy of repose, the privacy of sanctuary, and the privacy of intimate decision. These classes are different in the nature of the interest at stake and the showing required before protection will be granted. Within the classes such differences are minimal. When privacy is used as a catch phrase without some under-

9. Paul v. Davis, 96 S. Ct. 1155, 1166 (1976).

10. A recent and very thorough annotation on the right of privacy, Annot., $43 \mathrm{~L}$. Ed. 2d 871 (1976), illustrates this tendency. The outline of the annotation contains such subheadings as "Validity of state laws and regulations as affected by constitutional right of privacy," "Relation to Fourth Amendment," and "Relation to First Amendment; right of free speech and press." Only one subheading, entitled "Abortion Statutes," refers to the transaction that gave rise to the problem. 
standing of the distinctions between these classes, legitinate privacy interests may go unprotected because of the resulting confusion. The taxonomy of privacy interests proposed herein will simplify and clarify privacy analysis for courts and litigants alike.

I

\section{Spacting Mechanisms and Zones of Privacy}

The quest for privacy is not a phenomenon unique to human behavior. Animal psychologists have identified a natural need among various species of animals to establish individual boundaries and to restrict the entry of others into the area thus inarked off. ${ }^{11}$ "[E]ach animal is surrounded by a series of bubbles or irregularly shaped balloons that serve to maintain proper spacing between individuals."12 A number of these spacing mechanisms have been identified and described, each serving a different purpose. "Personal distance" is the term apphied to the normal spacing inaintained between animals of the same species. ${ }^{13}$ The approach of a potential eneiny within "flight distance" will trigger the animal's flight. ${ }^{14}$ If an enemy comes within the "critical distance," a cornered animal will attack. ${ }^{15}$ The boundaries of these various bubbles are criticial determinants of the behavior of the individual animals.

Justice Douglas recognized the existence of the same phenomenon in human behavior when he used the term "zones of privacy" in his opinion for the court in Griswold v. Connecticut ${ }^{16}$ and his dissent in Osborn v. United States. ${ }^{17}$ The boundaries that exist naturally in the animal world require legal recognition in the human realm before they can function as anything inore than amorphous urges. Courts faced with privacy questions in the past half-century have attempted to determine-albeit unknowingly at times-what the dimensions of the zones are, under what circumstances penetration within the zones will be allowed, and how dimension and penetrability vary with circuinstances.

Before any categorical description could take place, however, the very existence of the right to exclude others from some area surrounding one's life had first to be recognized. Arguing for such recognition in their famous article in 1890, Warren and Brandeis presented their concept of the principle of "inviolate personality."18 . Specifically, they

11. E. Hall, The Hidden Dimension 9 (1966).

12. Id. at 10 .

13. Id.

14. Id.

15. Id. at 11 .

16. 381 U.S. 479,484 (1965).

17. 385 U.S. 323,352 (1966).

18. Warren \& Brandeis, The Right to Privacy, 4 HARv. L. REv. 193, 205 (1890). 
defended the right of individuals to insist that some aspects of their personal lives be kept out of the newspapers. They did not speak of a zone of privacy, but they used a phrase that could have served as a crude functional description of one: the right "to be let alone."10 Brandeis used the phrase again in Olmstead, ${ }^{20}$ and many others have simce appropriated the term for their own use in circumstances very different from its original context. Nevertheless, the phrase is not rich enough in content to be useful as an analytical tool. The concept of a zone of privacy within which one is said to have a right to be let alone, without more clarity of definition, lacks discriminatory, descriptive, and predictive power.

Dean Prosser, in a 1960 law review article, ${ }^{21}$ attempted to bring some order into the analysis of privacy by concentrating on invasion of privacy as a tort and dividing it into four separate categories. ${ }^{22}$ But his analysis, arrived at after an extensive canvass of past cases, does not accommodate subsequent cases involving contraceptives, abortion, and state regulation of sexual and ingestive activities. Prosser, as a specialist on torts, focused his analysis on harm-causing activities that were proscribed rather than on zones to be protected. The Supreme Court rapidly outpaced his summary of the law of privacy and a new attempt at classification becaine necessary.

Many opinions explicitly discuss the right to privacy. Others make clear, without ever mentioning privacy, that the right in question is one akin to privacy. Courts embrace some abstract concept of zones of privacy when deciding cases, even if not articulated in terms of distances and boundaries. Three privacy zones, reflecting three separate and distinct concepts, emerge froin the decisions. The function of each zone is different, and the courts offer different protection to each.

II

\section{Methodology}

In the construction of a taxonomy of privacy rights, United States Supreme Court opinions play a predominant role. Some of the opiions examined here do not explicitly deal with privacy, but each case has contributed to the development of the zones of privacy concept and serves to illustrate the matrix within which future cases inust fit. Lower federal court and state court decisions are also discussed to demonstrate how the abstract primciples are being apphed to various fact situations.
19. Id. at 195.
20. See note 2 supra.
21. Prosser, Privacy, 48 CalIF. L. Rev. 383 (1960).
22. Id. at 389. 
Cases involving privacy touch upon issues that also fall within ntimerous other well-developed branches of the law. The present analysis does not investigate each of those numerous branches nor any one branch exhaustively. Rather, by presenting opinions sufficiently representative to demonstrate the development of a coherent concept of zones of privacy in judicial thought, it is hoped that clarity will be provided to the complex law of privacy.

III

\section{The Privacy of Repose}

Repose is freedom from anything that disturbs or excites. It partakes of calm, peace, and tranquility. If there is a right to reposethe right to be let alone in its most classic form-it is the most passive of privacies and the most dependent upon the sensory inipressions of the individual. Repose often conflicts with the activities and behavior of others who may interfere with repose by very passive activity or even by their inere existence. For example, freedom from being talked to can be guaranteed only if others are prevented from talking. Thus, other people's constitutionally protected rights, such as freedoin of speech and assembly, have frequently been granted precedence over repose by the Supreine Court.

\section{A. Repose at Home in Conflict with Various Categories of Speech}

A classic illustration of the Court's reluctance to protect repose when it conflicts with affirmative rights appeared in Martin $v$. Struthers, ${ }^{23}$ involving an industrial community where many inhabitants worked at night and slept during the day. The city banned knocking on the door or rimging the doorbell of a residence in order to dehiver handbills. The stated purpose of the ban was to protect householders from annoyance, invasion of privacy, and crime. ${ }^{24}$ In a decision limited to the particnlar facts, imvolving the free distribution of an invitation to religious services, the Court held the ordinance unconstitutional due to its restriction on the free exercise of first amendment rights. ${ }^{25}$ The Court emphasized that a less drastic ordinance that required a householder to hang out a "Do Not Disturb" sign would have achieved the legislative objective equally well. Thus, first amendment freedoms prevailed over the right to privacy unless the privacy clainn was staked out by means of a sign.
23. 319 U.S. 141 (1943).
24. Id. at 144.
25. Id. at 149. 
Eight years later, in Breard v. Alexandria, ${ }^{28}$ an ordinance banning solicitation of orders for the sale of goods at private residences without prior consent was upheld in the face of a challenge by magazine subscription salesmen. The distinction between this case and Struthers was plain to the majority. "[T]he living rights of [people] to privacy and repose"27 were not to be trampled by opportunists seeking private gain. Commercial speech was not so important that a legislative body could not prohibit its penetration into the zone of repose surrounding a home. ${ }^{28}$

This preference for the right of repose when in conflict with commercial speech continued in Rowan v. United States Post Office Department. $^{29}$ Here, however, the disturbance was not a knock on the door but the silent delivery of mail. A federal statute permitted householders to request that the Postmaster General issue an order directing a mailer to stop all further mailimgs to their households if they received advertisements from the sender offering matter that the individuals considered erotically arousing or sexually provocative. ${ }^{30}$ Publishers and mail service organizations claimed that the statute violated their constitutional right to communicate.

The Supreme Court disagreed. Calling attention to the similarity between this case and Martin v. Struthers, Chief Justice Burger discussed how the mailbox fit within the zone delineating the privacy of repose:

Weighing the highly important right to communicate, but without trying to determine where it fits into constitutional imperatives, against the very basic right to be free from sights, sounds, and tangible matter we do not want, it seems to us that a mailer's right to communcate inust stop at the mailbox of an unreceptive addressee. ${ }^{31}$

In Rowan no one's sleep was being disturbed; unwanted commercial advertising was merely dropped into a mailbox with the daily delivery. Yet the Court recognized a right to have some control over the sense impressions that enter a zone surrounding a person's home.

\section{B. Captive Auditors and Viewers Outside the Home}

The so-called loudspeaker cases involve attempts by various mumicipalities to protect the privacy of residents even outside their own

26. 341 U.S. 622 (1951).

27. Id. at 626 .

28. "A householder depends for protection on his city board rather than churlishly guarding his entrances with orders forbidding the entrance of solicitors." Id. at 640 .

29. 397 U.S. 728 (1970).

30. Id. at 729-30.

31. Id. at 736-37. 
homes. Saia v. New York ${ }^{32}$ held unconstitutional on its face an ordinance requiring a license from the chief of police before using sound amplification devices in public places. The five-menber majority was apparently not impressed by Frankfurter's dissent, warning of the dangers of "aural aggression" 33 inflicted by loudspeakers. Just 1 year later, the Court had occasion to decide a case alınost identical to Saia. In Kovacs v. Cooper ${ }^{34}$ an ordinance prohibiting the use of sound trucks emitting "loud and raucous noises" was upheld. The Court noted that a person "is practically helpless to escape this interference with his privacy by loud speakers except through the protection of the municipality." ${ }^{35}$ The difference between the two cases appears to be that the ordinance in Kovacs posed no danger of discretionary discrimination between noisy ideas-all loud and raucous sound trucks were prohibited. The Court did not want to subject first amendment rights to the discretion of a chief of police; but once the standard was changed to the more objective criteria of "loud and raucous," the right of citizens -even while not necessarily in the home-to peace and repose was given priority.

But the loudspeaker cases did not answer the crucial question of what types of stimuli a court will shield a person from outside the home. In Public Utilities Commission v. Pollack ${ }^{36}$ buses of the District of Columbia transit company carried FM receivers that broadcast music to passengers with soine infrequent news and commercial advertising. ${ }^{37}$ The Supreme Court held that coinplamants' argument that their constitutional right to privacy was being invaded rested on a false assumption that the "Fifth Amendment secures to each passenger on a [federally regulated bus] a right of privacy substantially equal to the privacy to which he is entitled in his own home."38 The holding demonstrates that there is no constitutional right of privacy of repose. ${ }^{39}$ It is deceptively easy to dismiss Pollack as an outdated holding, since repudiated by the Griswold reasoning that privacy is a constitutional right. A more accurate reconciliation of the two cases is that the rights asserted therein are not the same rights. They are rather two different species

32. 334 U.S. 558 (1948).

33. Id. at 563.

34. 336 U.S. 77 (1949).

35. Id. at 87.

36. 343 U.S. 451 (1952).

37. The complainants appealed a decision by the Public Utilities Commission of the District of Columbia approving the practice. The PUC liad before it evidence that most of the passengers on the buses approved of the broadcasts. 1d. at 459. The lower court had lield that at least the commercials and announcements infringed upon constitutional rights. Pollack v. Public Util. Comm'n, 191 F.2d 450, 458 (1951).

38. 343 U.S. at 464.

39. Id. at $467-68$. 
of the same genus: the right in Griswold belonging to a constitutionally protected species, ${ }^{40}$ and the right of repose in Pollack not constitutionally protected.

This is not to say that a legislature cannot make rules to protect the captive commuter. In Lehman v. City of Shaker Heights ${ }^{41}$ a cityoperated transit system sold commercial and public service advertising space on car cards but prohibited political or public issue advertising. Four members of the Court held that the rules were valid, helping the city to avoid charges of favoritism and sticky administrative problems, and to minimize the risk of imposing upon a captive audience. ${ }^{42}$ Justice Douglas concurred in the result, basing his opinion squarely on the right of the commuters to privacy on the buses. ${ }^{43}$ Thus, repose outside the home achieved a modicum of status.

\section{Balancing the Privacy of a "Captive" Against Speech Interests}

The two captive commuter cases provide some basis for predictions about the strength of the zone of repose outside the home. The mere fact that a person is a captive does not call into play a constitutional right of privacy. That fact will, however, make it more likely that the courts will allow a legislative body to protect the captive's privacy against disturbing influences. Yet legislative protections for the captive must not go too far.

In Cohen v. California ${ }^{4}$ the disturbing influence was a man wearing a jacket inscribed with the plamly visible words "Fuck the Draft" in a Los Angeles courthouse. The jacket-wearer was convicted under a California statute prohibiting "maliciously and willfully disturb[ing] the peace or quiet of any neighborhood or person, by ... . offensive conduct." ${ }^{45}$ The state argued that the defendant's behavior might properly be prohibited "to protect the sensitive from otherwise unavoidable exposure to [the] crude form of protest." 48 Since there was no actual or threatened violence, the issue was strictly one of privacy: could the state go this far in protecting the repose of unwilling and un-

40. See text accompanying notes 101-03 infra.

41. 418 U.S. 298 (1974).

42. The threshold issue was whether the card spaces were "public places," access to which had to be preserved for free speech. The four justices said that they were not, thus raising the inquiry of what rational purposes the city might have for such regulations. Id. at 304.

43. Id. at 307:

[T] he right of the commuters to be free from forced intrusions on their privacy precludes the city from transforming its vehicles of public transportation into foruns for the dissemination of ideas upon this captive audience.

44. 403 U.S. 15 (1971).

45. Cal. Penal Code $\$ 415$ (West 1970).

46. 403 U.S. at 21. 
suspecting viewers in a public place? The Court, per Justice Harlan, said that the state could not:

[T] he mere presumed presence of unwitting listeners or viewers does not serve automatically to justify curtailing all speech capable of giving offense.... [W] have ... consistently stressed that "we are often 'captives' outside the sanctuary of the home and subject to objectionable speech." 47

The Court, in spite of its sympathy for captive auditors and viewers, would not stretch the definition of "captive" to include persons who can avert their eyes or walk away. The likely inference follows that even if the Court did find that such persons had substantial privacy interests, freedom of speech might still be given priority. ${ }^{48}$

The Cohen rationale was followed in Erznoznik v. City of Jacksonville ${ }^{40}$ involving a challenge to the validity of an ordinance that prohibited showing films containing nudity on any drive-in movie theater screen visible from a public street or place. The Florida courts upheld the ordinance, but the Supreme Court reversed. The city contended inter alia that it could pass legislation to protect its residents' sensitivities. The screen in this case was visible from two adjacent public streets and a church parking lot. The Court admitted that selective restrictions on speech could be constitutional, but only if the auditor or viewer was at home or otherwise suffered a high degree of captivity. ${ }^{50}$ The Court reasoned that the screen of the drive-in theater was not so obtrusive that persons could not avert their eyes. ${ }^{51}$ "[T] ited privacy interests of persons on the public streets cannot justify this censorship of otherwise protected speech on the basis of its content." ${ }^{2}$ Classic balancing analysis is obviously at work here. But before bal-

47. Id. (citations omitted).

48. Similar intimations about the zone arose in Redrup v. New York, 386 U.S. 767 (1967), where three different obscenity holdings were reversed with the following explanation: "[In none of the cases] was there any suggestion of an assault upon individual privacy by publication in a manner so obtrusive as to make it impossible for an unwilling individual to avoid exposure to it." Id. at 769. The Court cited both Breard and Pollack. The inplication is that the obscenity holdings would have been upheld had there been any showing that the publication was so obtrusive that an unwilling viewer could not get away from it. Had the inaterial been visually "loud and raucous," it seems apparent that the Court would have favored privacy over free expression. Cf. Hess v. Indiana, 414 U.S. 105, 108 (1973) (per curiam); Gooding v. Wilson, 405 U.S. 518 (1972); Chaplinsky v. New Hampshire, 315 U.S. 568 (1942).

49. 422 U.S. 205 (1975).

50. Id. at 209.

51. The inajority ignored the portion of Chief Justice Burger's dissent that called attention to the difficulty of escaping an illuminated screen of great dimensions at night. Averting one's eyes, the Chief Justice thought, was hardly an adequate solution. Id. at 221.

52. Id. at 212 (einphasis added). 
ancing was attempted, the Court explicitly depreciated the privacy interest by noting that the persons affected were on public streets.

\section{IV}

\section{The Privacy of Samctuary}

In contrast with the zone of repose, which serves to block out certain stimuli from the zone, the purpose of the zone of sanctuary is to keep certain things within the zone. Repose means peace, quiet, and calm for the individual protected. Sanctuary means prohibiting other persons from seeing, hearing, and knowing. It is expressed in its most concrete and traditional form in the fourth amendment, ${ }^{68}$ which protects the right of the people to be secure not only against unreasonable searches, but also against unreasonable seizures.

The cases dealing with fourth amendment privileges and the exclusionary rule in criminal prosecutions often involve the removal of physical or tangible objects from a person's home or from other areas possessing the qualities of home, such as an office, store, hotel room, automobile, or taxicab. ${ }^{54}$ More interesting for purposes of privacy analysis are questions that deal with seizures of intangible matters such as sights, sounds, smells, and information. It is important to know how much protection courts are willing to give to the zone of sanctuary beyond the traditional fourth amendment protection, linited to tangible matter and impotent to restrain private parties.

A first step toward an answer is provicled by a study of the surveillance cases, where words spoken by a person are heard by government agents and the conversation is used as evidence against the speaker in a criminal prosecution. This line of cases begins with Olmstead $v$. United States, ${ }^{65}$ and the confrontation between Chief Justice Taft and Justice Brandeis provides great insight into two polar views of privacy. The Chief Justice had no desire to expand the meaning of the fourth amendment:

53. See, e.g., United States v. Calandra, 414 U.S. 338 (1974); Schneckloth v. Bustamonte, 412 U.S. 218 (1973); Bivens v. Six Unknown Named Agents, 403 U.S. 388 (1971); Wyman v. James, 400 U.S. 309 (1971); Camara v. Municipal Court, 387 U.S. 523 (1967); Mapp v. Ohio, 367 U.S. 643 (1961); Wolf v. Colorado, 338 U.S. 25 (1949); Weeks v. United States, 232 U.S. 383 (1914).

54. See Henry v. United States, 361 U.S. 98 (1959); United States v. Jeffers, 342 U.S. 48 (1951); Lustig v. United States, 338 U.S. 74 (1949); Brinegar v. United States, 338 U.S. 160 (1949); Davis v. United States, 328 U.S. 582 (1946); Gambino v. United States, 275 U.S. 310 (1927); Carroll v. United States, 267 U.S. 132 (1925); Gouled v. United States, 255 U.S. 298 (1921); Amos v. United States, 255 U.S. 313 (1921); Silverthorne Lumber Co. v. United States, 251 U.S. 385 (1920).

55. 277 U.S. 438 (1928). 
The reasonable view is that one who installs in his house a telephone instrument with connecting wires intends to project his voice to those quite outside, and that the wires beyond his house and inessages while passing over them are not within the protection of the Fourth Amendment. ${ }^{5 B}$

With this statement Chief Justice Taft introduced the idea that the subject's expectations of privacy may resolve the question whether the law will protect the privacy interest. The statement implies that a person who talks on a telephone and knows that the words are going outside the zone of sanctuary can reasonably expect no privacy. Taft's ideas about wiretapping have since been rejected, ${ }^{37}$ but his notion of the subjective expectations of privacy has prevailed to this day.

Justice Brandeis felt a passionate regard for sanctuary regardless of the expectations of reasonable persons. He reached back to his article with Warren almost 40 years earlier ${ }^{58}$ for much of his dissent:

The makers of our Constitution undertook to secure conditions favorable to the pursuit of happiness. ... They conferred, as against the Governinent, the right to be let alone-the most comprehensive of rights and the right most valued by civilized men. To protect that right, every unjustifiable intrusion by the Government upon the privacy of the individual, whatever the ineans employed, must be deemed a violation of the Fourth Amendment. 59

The ideas championed by Justice Brandeis that gave concrete expression to the concept of an impenetrable zone of sanctuary (at least vis-àvis the government) have been echoed in numerous dissents since Olmstead. $^{\text {Bo }}$

\section{A. Government Removal of Information With Accomplices}

Chief Justice Taft's views, limiting fourth amendment protection to those interests about which an individual could demonstrate a reasonable expectation of privacy, continue to have great force. In Lopez v. United States ${ }^{61}$ the defendant had offered to bribe an Internal Revenue agent. The agent played along with the offer and recorded subsequent conversations with a concealed recorder. Lopez contended that his words had been illegally seized. The Court held that Lopez had assumed the risk that the offer would be reproduced in court; if

56. Id. at 466 .

57. See text accompanying notes 73-75 infra.

58. See note 18 supra.

59. 277 U.S. at 478.

60. See, e.g., Public Util. Comm'n v. Pollack, 343 U.S. 451, 467-68 (1952) (Douglas, J., dissenting); United States v. White, 401 U.S. 745, 756 (1971) (Douglas, J., dissenting).

61. 373 U.S. 427 (1963). 
not by the recording then at least by means of the potentially flawless memory of the agent. Lopez could thus claim no zone of privacy, because a reasonable person would not expect privacy while speaking to an Internal Revenue agent.

Other cases make it perfectly plain that the privacy interest may go unprotected even where the government accomplice is not such an obviously dangerous confidant as an Internal Revenue agent. The Court has upheld convictions based upon evidence where the wired accomplice was an acquaintance of the defendant, ${ }^{82}$ where the government agent was a person hired by the defendant to do investigative work for him, ${ }^{63}$ and where the imformer was a fellow union official invited to defendant's hotel suite. ${ }^{64}$ In the latter case the Court held that the zone of sanctuary did not prevent the government from using the subject's own words once privacy protection was waived by making the words public to at least one person: "Neither this Court nor any meinber of it has ever expressed the view that the Fourth Amendment protects a wrongdoer's misplaced belief that a person to whom he voluntarily confides his wrongdoing will not reveal it. ${ }^{85}$

Even the watershed decision in wiretapping law, Katz $v$. United States ${ }^{68}$ did not alter the judicial attitude toward consensual interception of conversations. The most prominent post-Katz case, United States $v$. White, ${ }^{67}$ determined that the boundaries of the zone of sanctuary are not sufficiently strong to keep the state from hearing what an individual voluntarily confides to someone in league with the state. In White a government informant carried a transmitter to enable government agents to overhear conversations with the defendant in a restaurant, in the informer's car, and in their homes. The Court's plurality decision upheld the conviction based upon the agents' testimony. Only four of the justices felt that the defendant had no reasonable expectation of privacy:

Our problem is not what the privacy expectations of particular defendants in particular situations may be or the extent to which

62. The Court in On Lee v. United States, 343 U.S. 747 (1952), upheld a conviction based on incriminating statements made by the defendant in his own shop to an old acquaintance who was wired to transmit the conversation to a narcotics agent outside.

63. Osborn v. Umited States, 385 U.S. 323 (1966).

64. Hoffa v. United States, 385 U.S. 293 (1966).

65. Id. at 302. For a general discussion of the issue, see Greenawalt, The Consent Problem in Wire-Tapping and Eavesdropping, 68 CoLUM. L. Rev. 189 (1968); Kitch, Katz v. United States: The Limits of the Fourth Amendment, 1968 Sup. Cr. Rev. 133; Note, Judicial Control of Secret Agents, 76 Yale L.J. 994 (1967). See also Holmes v. Burr, 486 F.2d 55, 60 (9th Cir. 1973) (Hufstedler, J., dissenting), cert. denied, 414 U.S. 1116 (1973).

66. 389 U.S. 347 (1967). See text accompanying notes 73-75 infra.

67. 401 U.S. 745 (1971). 
they may in fact have rehed on the discretion of their companions. ... Our problem, in terms of the principles announced in Katz, is what expectations of privacy are constitutionally "justifiable" $\ldots .{ }^{88}$

Justice Black concurred in the result because of his consistently articulated view that the fourth amendment protects privacy only to the extent that it prohibits unreasonable searches and seizures of persons, houses, papers, and effects. ${ }^{69}$ Thus, a majority of the Court in effect supported the proposition that there can never be a reasonable expectation that another person might not betray confidences. Two years after White, a court of appeals was able to cite decisions from nine different circuits upholding the constitutionality of consensual interception of oral communication. ${ }^{70}$

\section{B. Governmental Removal of Information Without Accomplices}

The law of nonconsensual bugging has not been so static. Olmstead permitted the direct tapping of telephone wires to an office. In 1967 two cases changed the law. Berger v. New York ${ }^{71}$ struck down a state statute that allowed an exparte order for eavesdropping upon reasonable behef that evidence of a crime would be obtained thereby:

Our concern with the statute here is whether its language permits a trespassory invasion of the hoine or office, by general warrant, contrary to the command of the Fourth Amendment. As it is written, we believe that it does.72

In effect, the holding suddenly brought the telephone wires that Chief Justice Taft had banned from the zone of sanctuary within that zone's borders of protection. But it is legitimate to ask what conditions had changed sufficiently to account for the increased protection. The nature of "persons, houses, papers and effects," specified in the fourth amendment, had not changed. The physical relationship of telephones to the constitutionally protected categories had not changed. What had changed was the nunber of telephones in the country, and the concomitant change in status from luxurious busmess equipment to necessity of modern life. The Court in Berger implied that people expected privacy by the use of the words "trespassory invasion." The language clearly negates the view that the holding was an example of the Court suddenly deciding that government intrusion of this type, though anticipated by any reasonable person, was not to be allowed in the future.

68. Id. at 751-52.

69. Id. at 754 (Black, J., concurring).

70. Holmes v. Burr, 486 F.2d 55, 58 (1973). But see Judge Hufstedler's dissent, id. at 73 n.30.

71. 388 U.S. 41 (1967).

72. Id. at 64 . 
It is clearly a case of the Court responding to the changing contours of the reasonable expectation standard.

The landmark case in wiretapping law, Katz v. United States, ${ }^{78}$ did nothing to change this essential analytical point. The petitioner had been convicted on the basis of conversations that the FBI had recorded by attaching an electronic device to the outside of a public telephone booth. Justice Stewart adhered to the tradition begun by Taft:

What a person knowingly exposes to the public, even in his own home or office, is not a subject of Fourth Amendnent protection. But what he seeks to preserve as private, even in an area accessible to the public, may be constitutionally protected. ${ }^{74}$

It was still vital to the Court that the zone of privacy extend only so far as a reasonable person might expect. The revolution brought about by Katz inhered in the Court's novel finding that privacy on a telephone, even one located in a public booth, was in fact a reasonable expectation. ${ }^{75}$

The Katz opinion allowed for an expansion of the zone of sanctuary to mclude telephone wires and booths while still leaving other situations where nonconsensual interception of conversations could be allowed. One such situation arose in Lanza v. New York, ${ }^{76}$ where petitioner complained that evidence used against him had been obtained by secret recording of a conversation he had with his brother in a jail. The Court noted that a jail was not a home, an automobile, an office, or a hotel room. "In prison, official surveillance has traditionally been the order of the day."77 Since Lanza had no expectation of privacy, he had no zone of sanctuary once he entered the prison.

73. 389 U.S. 347 (1967).

74. Id. at 351-52 (citations omitted).

75. This conclusion is unavoidable when one reads the concurring opinion by Justice Harlan:

My understanding of the rule that has emerged from prior decisions is that there is a two-fold requirement, first that a person have exhibited an actual (subjective) expectation of privacy and, second, that the expectation be one that society is prepared to recognize as "reasonable." Thus a man's home is, for most purposes, a place where he expects privacy, but objects, activities, or statements that he exposes to the "plain view" of outsiders are not "protected" because no intention to keep them to himself has been exhibited. On the other hand, conversations in the open would not be protected against being overheard, for the expectation of privacy under the circumstances would be unreasonable.

Id. at 361. Justice Stewart's opinion carries a terser message:

The Government's activities in electronically listening to and recording the petitioner's words violated the privacy upon which he justifiably relied while using the telephone booth and thus constituted a "search and seizure" within the meaning of the Fourth Amendment.

Id. at 353.

76. 370 U.S. 139 (1962).

77. Id. 
Litigants should not be misled into believing that the reasonable expectation standard is applied solely to wiretapping or eavesdropping cases. It is a standard that all courts apply whenever one of the issues is whether the government can intrude upon the zone of sanctuary to extract incriminating data. ${ }^{78}$ In United States $v$. Solis, ${ }^{79}$ a recent Ninth Circuit case, the defendant had parked a trailer containing 1 ton of marijuana covered with talcum to mask the odor behind a gasoline station. Upon receiving a tip from an informant, two customs officials approached the trailer with specially trained marijuana-sniffing dogs. The dogs reacted positively. A magistrate thereupon issued a search warrant, and Solis was indicted for possession with intent to distribute and distribution of marijuana. The lower court granted defendant's motion to suppress the evidence. ${ }^{80}$ The court of appeals reversed, embracing the reasonable expectation of privacy test articulated in Katz. ${ }^{81}$ The opmion cited many reasons for the holding, including two that demonstrated the court's belief that Solis had no reasonable expectation of privacy. First, the trailer was parked in an area open to the public. Second, "[t]here was an expectation that odor would emanate from the trailer. Efforts made to mask it were visible."82 The court believed that if Solis had expected privacy, he would not have covered the inarijuana with talcuin. ${ }^{83}$

There is a paradox here that highlights a problem with the reasonable expectations test. The defendant was impaled on the horns of the dilemina generated by Justice Harlan's two-pronged test in Katz. ${ }^{84}$ Solis had covered the contraband with talc, and thus failed the first test of actual expectation of privacy. If, however, he had exposed the inarijuana to the "plain view of outsiders," in Harlan's words, he would have

78. Ignoring this almost universal standard can lead to some anomalous pleadings. In Air Pollution Variance Bd. v. Western Alfalfa Corp., 416 U.S. 861 (1974), a firm was ordered to cease emitting excessive pollutants from its smokestacks. The pollution level had been ineasured by an inspector while on the defendant's premises, but the Court based its holding that the measuring procedure was not an invasion of privacy on the fact that the smoke was visible for miles. It is indeed difficult to imagine how privacy could be reasonably expected in such circumstances. It should also be noted that the Court has at least twice before held that corporations enjoy no right of privacy. Joint Anti-Fascist Refugee Comm. v. McGrath, 341 U.S. 123, 184 (1951) (Jackson, J., concurring); United States v. Morton Salt Co., 338 U.S. 632, 652 (1950). But cf. Kewanee Oil Co. v. Bicron Corp., 416 U.S. 470 (1974).

79. 536 F.2d 880 (9th Cir. 1976).

80. United States v. Solis, 393 F. Supp. 325 (C.D. Cal. 1975).

81. 536 F.2d at 882 .

82. Id.

83. For other cases admitting similarly obtained evidence, see United States v. Bronstein, 521 F.2d 459 (2d Cír. 1975); United States v. Fulero, 498 F.2d 748 (D.C. Cir. 1974).

84. See note 75 supra. 
had no protection because no intention to keep the secret to himself would have been exhibited.

There is yet another difficulty with the reasonable expectations test. In his dissent in United States $v$. White, Justice Harlan pointed an accusing finger at courts for adopting too wholeheartedly the standard he had so clearly articulated in Katz:

Our expectations, and the risks we assume, are in large part reflections of laws that translate into rules the custons and values of the past and present.

Since it is the task of the law to form and project, as well as mirror and reflect, we should not, as judges, merely recite the expectations and risks without examining the desirability of saddling them upon society. ${ }^{85}$

People learn to expect privacy in certain situations because courts give notice that in such situations the privacy interest is protected. For the courts then to say that privacy will be protected only where people expect such protection is a circular avoidance of responsibility. A more direct inquiry would be whether society is willing to grant privacy in any given situation, whether or not it is expected.

\section{Removal of Private Facts by Private Parties}

In spite of difficulties with the particular standards to be applied, the cases show that the state is precluded from using its eyes, ears, or noses to penetrate any area where society recognizes the right of an individual reasonably to expect privacy. Eut the state is not the only entity capable or desirous of observing an individual's activities. Private-parties inay also prove bothersome to one who wishes to keep personal information private. Our culture and the legal doctrines within it support the exercise of that wish up to a point. ${ }^{86}$ Nonetheless, privacy takes a subordinate rank in the pecking order of fundamental rights.

The Hill family had the misfortune of being held hostage in its hoine by three escaped convicts. The incident inspired a novel, and later a play. The play in turn inspired a picture story in Life magazine showing the cast of the play reenacting scenes from the play in the Hill's former home. The play depicted the infliction of violence upon the hostage family, whereas the convicts had in fact inflicted no violence. Hill won a judgment against the inagazine under a New York privacy statute, ${ }^{87}$ which required one of two showings to obtain recovery: lack

85. United States v. White, 401 U.S. 745, 786 (1971).

86. Prosser, note 21 supra, at 386-88.

87. N.Y. CIV. RIGHTS LAW $\S \S 50-51$ (McKinney 1948). 
of newsworthiness, or material and substantial falsification. In Time, Inc. v. Hill, ${ }^{88}$ the Court reversed, preferring the constitutional freedoms of speech and press over privacy (at least in matters of public interest) unless the defendant published the report "with knowledge of [its] falsity or in reckless disregard of the truth." outside the scope of this analysis, but the "newsworthmess" or "matter of public interest" test is merely a corollary to the reasonable expectation standard. It is unreasonable, according to Hill, to expect privacy if one is unlucky enough to be involved in an event others find newsworthy. ${ }^{90}$ Such reasoning may be defensible when the subject of a story is a public official who has consciously chosen and benefitted from public life; $; 1$ there the newsworthmess standard grows out of familiar legal doctrines of implied conditions or assumption of risk. When applied to private individuals, however, the standard lacks compassion and consistency. Another troubling aspect of this contraction of the zone of sanctuary is that the Court gives no hint of low long after a newsworthy event a person inust wait before reasserting the right of privacy. ${ }^{92}$

The articulation of the newsworthiness standard in Hill aroused fears that the decision of any one managing editor to print or not to print would deternine whether an individual's private life would reinam private. ${ }^{93}$ A recent Ninth Circuit case, Virgil v. Time, Inc. ${ }^{94}$ lays some of these fears to rest. In Virgil a surfer gave interviews to a sports magazime and consented to their publication. When he realized

88. 385 U.S. 374 (1967).

89. Id. at 394.

90. Justice Douglas made this clear in his concurring opinion:

It seems to me irrelevant to talk of any right of privacy in this context. Here a private person is catapulted into the news by events over which he had no control. He and his activities are then in the public domain as fully as the matters at issue in New York Times Co. v. Sullivan, 376 U.S. 254. Such Id. at 401. privacy as a person normally has ceases when his life has ceased to be private.

91. See New York Times Co. v. Sullivan, 376 U.S. 254 (1964).

92. See Briscoe v. Reader's Digest Ass'n, 4 Cal. 3d 529, 483 P.2d 34, 93 Cal. Rptr. 866 (1971).

93. Cf. Kalven, The Reasonable Man and the First Amendment: Hill, Butts, and Walker, 1967 Sur. Cr. Rev. 267, 283-84:

Although it was not necessary in Hill to delineate the outer boundaries of the newsworthy, the Court may be surprised by the extent of its commitment. . . . Newsworthiness will almost certainly become a descriptive and not a normative term. In brief, the press will be the arbiters of it and the Court will be forced to yield to the argument that whatever the press prints is by virtue of that fact newsworthy. This has been pretty much the experience with the common-law policy. ... The upshot, and it is an important one, is that the logic of New York Times and Hill taken together grants the press some measure of constitutional protection for anything the press thinks is a matter of public interest.

94. 527 F.2d 1122 (9th Cir. 1975), cert. denied, 96 S. Ct. 2215 (1976). 
that the article went beyond his activities as a surfer and probed into his private life, he revoked his consent. Nonetheless, the article was pubhished, and the surfer sued for invasion of privacy. Time, Inc. moved for summary judgment, contending that since Virgil did not deny the truth of the statements made, the publication was privileged under the first amendment. The district court demied the motion. On interlocutory appeal, the court of appeals remanded, noting that not every truth is newsworthy:

To hold that [the first amendment] privilege extends to all true statements would seem to deny the existence of "private" facts ... .

... Does the spirit of the Bill of Rights require that individuals be free to pry into the unnewsworthy private affairs of their fellowmen? In our view it does not. In our view fairly defined areas of privacy must have the protection of law if the quality of life is to continue to be reasonably acceptable. The public's right to know is, then, subject to reasonable limitations so far as concerns the private facts of its individual members.

... The press, then, cannot be said to lave any right to give information greater than the extent to which the public is entitled to have information.

We conclude that unless it be privileged as newsworthy ... the publicizing of private facts is not protected by the First Amendment. ${ }^{95}$

The court's rationale admittedly did not make the newsworthiness standard any easier to manage. The court did, however, establish that the newsworthiness decision is not to be entrusted entirely to journalists.

Since the culture-dependence of newsworthmess makes it a difficult standard for courts to apply, it follows that legislatures might seek to define the term more exactly to fit local mores. Such was the case in Cox Broadcasting Corp. v. Cohn. ${ }^{98}$ In Georgia, both common law and a statute prohibited public dissemimation of the identity of any female rape victim. In the course of a news story a television station broadcast the name of a woman who had been raped. The Court reversed the lower court's judgment in favor of the victim's father, reasoning that since the victim's name was already in the public domain (via official court records), "the prevailing law of invasion of privacy generally recognizes that the interests in privacy fade . . .."97 Thus, even though state law had defined what was reasonable under the circumstances, the Court found that constitutional imperatives rendered the expectation unreasonable.

95. 527 F.2d at 1128 (footnotes omitted).

96. 420 U.S. 469 (1975).

97. Id. at 494 . 


\section{Publication of "Private" Facts by Public Officials}

A similar problem of records in the public domain gave rise to Paul v. Davis, ${ }^{98}$ which was unusual in that it required the Court to decide whether the Constitution permitted invasion of the zone of sanctuary for reasons other than first amendment rights or gathering evidence for a criminal prosecution. Edward Davis was arrested in Louisville, Kentucky, on a charge of shoplifting and pleaded not guilty at his arraignment. The charge was filed away with leave to reinstate, thus leaving it outstanding for a period of time. During that period, two local chiefs of police distributed a flyer to approximately 800 merchants in the Louisville metropohitan area. The flyers consisted of five pages of mug shots with names arranged alphabetically, each page headed with the words "active shoplifters." Davis' name and picture appeared in the flyer. Shortly thereafter the charge against Davis was dismissed.

Because the acts were committed by state officials, Davis brought an action under section 1983 of title 42 of the Uinited States Code, which required a showing that Davis had been deprived of a right secured by the Constitution. One of the rights he claimed was a "right to privacy guaranteed by the First, Fourth, Fifth, Ninth, and Fourteenth Amendments." The Court rejected this claim. Justice Rehnquist, writing for the Court, pointed out that the activities that had been protected in the Court's prior privacy decisions were very different from those for which Davis claimed constitutional protection:

Respondent's claim is far afield from this line of decisions. He claims constitutional protection against the disclosure of the fact of his arrest on a shoplifting charge. His claim is based not upon any challenge to the State's ability to restrict his freedom of action in a sphere contended to be "private," but instead on a claim that the State may not publicize a record of an official act such as an arrest. None of our substantive privacy decisions hold this or anything hike this, and we dechine to enlarge them in this manner. ${ }^{100}$

The tone of the opinion, epitomized by the curtness of the emphasized phrase, illustrates the Court's belief that it is unreasonable to expect the Constitution to protect privacy after a person has been arrested. There is not the slightest intimation that any publication of an arrest might violate a right of privacy. There is merely a statement that publication of an official act sucl as an arrest is not a violation. Paul v. Davis forcefully rebuts the argument that Griswold and its progeny have recognized a generalized, constitutionally protected right of privacy.

\footnotetext{
98. Paul v. Davis, 96 S. Ct. 1155 (1976).

99. Id. at 1166 .

100. Id. (emphasis added).
} 


\section{The Privacy of Intimate Drcision}

The privacy of intimate decision is an eminently dynamic privacy concept compared to repose and sanctuary. The zone of intimate decision is an area within which the personal calculus used by an individual to inake fundamental decisions must be allowed to operate without the injection of disruptive factors by the state. This privacy is less "freedoin from" and inore "freedoin to." It is also the privacy that courts refer to in almost all the cases that discuss a constitutional right to privacy.

The constitutional right to privacy was first articulated and nost carefully developed in a series of cases that touched upon one of life's most intimate concerns: procreation. The first case explicitly to recognize the privacy of intimate decision was Griswold v. Connecticut.101 In finding a right to privacy, the Court differed greatly as to the source and foundation of the right. An exhaustive inquiry into the threads of tradition and doctrine used in weaving the fabric of privacy has been provided elsewhere. ${ }^{102}$ This Comment is concerned with what intiinate decisions Griswold drew within the zone of privacy that is shielded froin state intervention.

Griswold established the existence of a zone within which inarried persons are free to decide whether to use contraceptives without interference froin the state. ${ }^{103}$ It was unclear, however, whether the auton-

101. 381 U.S. 479 (1965).

102. For an exhaustive discussion of the four diverse rationales for the Griswold decision and its potential consequences, see Symposium on the Griswold Case and the Right of Privacy, 64 Mich. L. REv. 197 (1965).

103. The Connecticut statute underlying the Griswold controversy provided for fine or imprisonment or both for any person who used any drug, medicinal article, or instrument for the purpose of preventing conception. The convictions in the case werc overturned because the Court held that the statute violated the constitutional right of privacy. Justice Douglas, writing for the Court, was most concerned that the statute interfered with a special decision normally made within the framework of a long-recognized legal relationship: "This law ... operates directly on an intimate relation of husband and wife and their physician's role in one aspect of that relation." 381 U.S. at 482 . It is not clear from the language of the opinion whether tlie important factor for the Court was protection of the particular decision or protection of the sanctity of the marital relationship:

[The present case] concerns a law which, in forbidding the use of contraceptives rather than regulating their manufacture or sale, seeks to achieve its goals by means having a maximum destructive impact upon that relationship.

Id. at 485. Justice Goldberg also concentrated on the right of marital privacy in his concurring opinion. Nevertheless, he too believed that privacy demanded that the state be barred from interfering with autonomous decisionmaking:

Surely the Government, absent a showing of a compelling subordinating state interest, could not decree that all husbands and wives must be sterilized after two children have been born to them. . . . While it may shock some of my Brethren that the Court today holds that the Constitution protects the right 
omy recognized in Griswold was conferred only upon married couples. Eisenstadt v. Baird ${ }^{104}$ subsequently extended the scope of the zone by recognizing that the right to make such a decision was an individual right, independent of marriage. In Eisenstadt the Court considered a Massachusetts law that made distribution of contraceptive materials a felony, except by registered physicians and pharmacists to married persons. The Court could find no rational explanation for the difference in treatment between married and unmarried persons:

It is true that in Griswold the right of privacy in question inhered in the marital relationship. ... If the right of privacy means anything, it is the right of the individual, married or single, to be free froin unwarranted governmental intrusion into matters so fundamentally affecting a person as the decision whether to bear or beget a child. ${ }^{105}$

Eisenstadt declared that the purpose of the zone established in Griswold was to protect decisionmaking of an intimate or fundamental nature and did not depend upon an intimate relationship such as marriage for its vitality.

Yet it was still unclear if the decisionmaking protected was whether to use contraceptives or whether to have children. The answer was forthcoming in Roe v. Wade ${ }^{106}$ and its companion, Doe v. Bolton. ${ }^{107}$ "The right of privacy . . . is broad enough to encompass a woman's decision whether or not to terminate her pregnancy."108 The two cases held that rights that could be deemed fundamental or "implicit in the concept of ordered liberty"109 could be included in the zone of privacy. With this analysis, however, another important element was added to privacy doctrine. The state was to be allowed to invade the zone in order to protect compelling state interests, such as health, maintenance of medical standards, and protection of potential life. ${ }^{110}$ The Court concluded by establishing guidelines that indicated at what point during pregnancy the decision to abort was no longer solely in the hands of a woman and her physician. ${ }^{111}$

of marital privacy, in my view it is far more shocking to believe that the personal liberty guaranteed by the Constitution does not include protection against such totalitarian limitation of family size . . . .

Id. at 496-97.

104. 405 U.S. 438 (1972).

105. Id. at 453 .

106. 410 U.S. 113 (1973).

107. 410 U.S. 179 (1973).

108. Roe v. Wade, 410 U.S. 113, 153 (1973).

109. Id. at 152.

110. Id. at 154 .

111. Id. at 164-65. See also Planned Parenthood v. Danforth, 96 S. Ct. 2831, 2840 (1976), which makes it plain that the father has no inherent right to participate in the decision. 
It is important to recognize that the Court's concern for autonomous decisionmaking is and has been an important factor in motivating holdings that make no mention of the right to privacy. For instance, Skinner v. Oklahoma ex rel. Williamson, ${ }^{112}$ decided many years before Griswold, is clearly a privacy case. The Court held an Oklahoina law authorizing sterilization of persons convicted of certain felonies involving moral turpitude more than twice violative of equal protection. A decision to be sterilized was clearly an intimate decision. "We are dealing here with legislation which involves one of the basic civil rights of unan. Marriage and procreation are fundamental to the very existence and survival of the race." 113 Similarities of language between Griswold and Skinner are no coincidence; both opinions were written by Justice Douglas. Once he had found Oklahoma's eugenic theory to be without basis in fact, ${ }^{114}$ there was no compelling state interest ${ }^{116}$ that might allow the state to penetrate the zone of privacy and interfere with a fundamental decision. ${ }^{116}$

Cleveland Board of Education v. LaFleur ${ }^{117}$ also illustrates how the Court uses privacy zone reasoning without ever mentioming privacy. LaFleur is a paradigm of intimate decision thinking. But the opinion illustrates a further point: fundamental decisions about procreation are to be protected agamst even oblique interference. The school board in LaFleur required pregnant teachers to take leave without pay at least 5 months before the expected date of birth. Obviously, the state was not directly prohibiting any decision; it was merely adding a deterrent to 'teachers' bearing children. The Court found no coinpelling interest to justify such a broad intrusion affecting a basic civil right of women. That the interference was only indirect did not relieve the state of its heavy burden to show some such compelling interest. The Court supported its contention that matters of personal choice in marriage and family life are constitutionally protected by citing an extensive list of cases treated here as intimate decision holdings, without once mention-

112. 316 U.S. 535 (1942).

113. Id. at 541 .

114. Id. at 542 .

115. In Buck v. Bell, 274 U.S. 200 (1927), the Court, per Justice Holmes, had sanctioned a sterilization procedure that was to be performed on a feeble-minded woman whose mother was feeble-minded and whose illegitinate daughter was feeble-minded. Apparently, eugenic theories were used to show a compelling state imterest. Justice Holmes also pointed out that the operation made it possible to release the woman from an institution without further burdening the state.

116. "[Skinner] rested not upon a belief that the Court was well qualified to resolve issues about heredity, but rather upon a sense that interference with something as fundamental to the individual as procreation should be subjected to close scrutiny." Note, Developments in the Law-Equal Protection, 82 HARv. L. REv. 1065, 1129 (1969).

117. 414 U.S. 632 (1974). 
ing privacy. ${ }^{118}$ Once sufficient precedent establishes that a fundamental decision is protected, the state may be prohibited from making even very indirect rules that influence an individual's decision calculus. If used with care, this concept may provide rich support for a variety of cases in the future. ${ }^{110}$

In addition to the right of procreation, there are other riglits and fact situations that provide further insight into how the zone of intimate decision functions. Some of the important cases were decided long before Griswold, and others do not mention privacy at all. . Nonetheless they too contribute to an understanding of the zone. The clearest way to illustrate the operation of the zone of intinate decision is to examine the types of intimate decisions it protects, taking into consideration the various factors which strengthen or weaken that protection.

\section{A. Cohabitation Decisions}

Loving $v$. Virginia ${ }^{120}$ reversed a state court decision that upheld a Virginia statutory schenne prohibiting racially mixed inarriages. The Court answered the crucial initial question of any intimate decision analysis-is this decision a fundamental decision inherent in the human condition?- by borrowing froin Skinner. "Marriage is one of the "basic civil rights of inan,' fundamental to our very existence and survival."121 The Court rejected the contention that the state had a legitimate interest in preserving the "racial integrity of its citizens" 122 and preventing "a mongrel breed of citizens." 123 Thus, the state had no compelling interest to justify penetrating the zone of intimate decision. Although the Court never mentioned a right of privacy in the opimion, Loving is generally considered to be a privacy case. ${ }^{124}$

Since it seemed so clear that decisions about family size and nnarriage partner were protected within the intimate decision zone, it was reasonable to suppose that the choice of living partner might also be constitutionally protected agaimst state interference. The issue was posed in Belle Terre v. Boraas, ${ }^{125}$ where a local zoning ordinance limited the number of unrelated individuals who could live in a one-family

118. Id. at 640 .

119. But cf. Belle Terre v. Boraas, 416 U.S. 1 (1974); text accompanying notes 12527 infra; United States v. 12200 Foot Reels, 413 U.S. 123 (1973); text accompanying note 152 infra.

120. 388 U.S. 1 (1967).

121. Id. at 12 .

122. Id. at 7 .

123. Id.

124. See Cleveland Bd. of Educ. v. LaFleur, 414 U.S. 632, 640 (1974); Roe v. Wade, 410 U.S. 113, 152 (1973).

125. 416 U.S. 1 (1974). 
dwelling. The Court upheld the restriction, holding that it infringed upon no fundamental right guaranteed by the Constitution, not even the right of privacy. Justice Marshall dissented from the view that the personal decision involved was not within the zone:

The choice of household companions-of whether a person's "intellectual and emotional needs" are best met by living with family, friends, professional associates, or others--involves deeply personal considerations as to the kind and quality of intimate relationships within the home. That decision surely falls within the ambit of the right to privacy protected by the Constitution. ${ }^{126}$

The Court, however, rejected the idea that such a decision was fundamental or intimate enough to be within the zone of intinate decision ${ }^{127}$ and refused to extend the protection of choice of marital partner, accorded by Loving, to choice of cohabitant.

Belle Terre is an instructive interruption in the transitive development of intimate decision theory. Griswold is clearly linked to Loving; the link between Loving and Belle Terre proved impossible to forge. Certainly the decision of whoin to live with is intimate. Yet underlying the Court's rationale in Belle Terre was the unspoken recognition that the intimate decision at issue was merely a foundation for a lifestyle associated with many other decisions that were certainly not private, and almost all of which were antithetical to the majority views of the community. Whenever a court perceives that an intinate decision will inevitably facilitate or lead to other decisions that may not be intimate and nay be undesirable, the privacy interest in question is more likely to be left unprotected, no matter how fundamental or intinate it seeins when viewed in isolation.

\section{B. Child-Rearing Decisions}

Another pre-Griswold case cited with Loving in hists of privacy cases is Pierce $v$. Society of Sisters. ${ }^{128}$ Pierce illustrates another personal decision that will be protected: the education of one's children. The Court struck down a state statute requiring that virtually all children be sent to public schools, finding that it "unreasonably interfere[d] with the liberty of parents and guardians to direct the upbring-

126. Id. at 16.

127. Cf. Atkisson v. Kern County Housing Authority, 59 Cal. App. 3d 89, 130 Cal. Rptr. 375 (5th Dist. 1976), where the court held that a public housing authority's rule that forbade tenants from living with anyone of the opposite sex to whom the tenant was not related by blood, marriage, or adoption, might effectively prevent unwed parents from liviug with and raising their own children and was thus an invalid infringement upon the right of privacy.

128. 268 U.S. 510 (1925). 
ing and education of children under their control."128 This is quintessential privacy reasoning, and suggests that many child-rearing decisions may be within the zone of intimate decision. ${ }^{130}$ Not all childrearing decisions, however, are within the zone. In Prince v. Massachusetts $^{131}$ the Court declared its respect for the zone of intimate decision, but this respect did not deter it from deciding that the state could interfere to soine extent with a guardian's decisions about childrearing. It upheld a state law making it a crime for children to sell merchandise in public places as applied to a child distributing religious literature with her guardian. ${ }^{132}$ The Court noted the "crippling effects of child employment," ${ }^{\prime 33}$ and found that a compelling state interest in the healthy growth of children allowed the state to penetrate the zone to regulate certain child-rearing decisions, just as a compelling interest 30 years later allowed the state to regulate abortions.

\section{Bodily Integrity Decisions}

Justice Blackmun asserted in Roe that the right of privacy does not include the unlinited right to do with one's body as one wishes. ${ }^{134}$ Several other cases establish the proposition that a great many personal decisions about how one treats one's body are not intimate or private enough to allow the courts even to engage in privacy analysis. A very old case that illustrates typical conflicting interests is Jacobson v. Massachusetts, ${ }^{135}$ where a state statute authorizing compulsory vaccinations was upheld as applied to a person who objected on religious grounds. In such a case, a court could presunably argue quite convincingly that even though the decision to subinit to vaccination might be protected within the zone of intimate decision, there is a compelling state interest in the prevention of epidemics that justifies interference. In fact, however, courts have simply found that the decision to risk sinallpox is not fundamental enough to fall within the zone in the first place.

129. Id. at 534-35.

130. See also Wisconsin v. Yoder, 406 U.S. 205 (1972); West Virginia State Bd. of Educ. v. Barnette, 319 U.S. 624 (1943); Meyer v. Nebraska, 262 U.S. 390 (1923).

131. 321 U.S. 158 (1944).

132. Id. at 166 (citations oinitted):

It is cardinal with us that the custody, care and nurture of the child reside first in the parents, whose primary function and freedoin include preparation for obligations the state can neither supply nor hinder. And it is in recognition of this that these decisions have respected the private realm of family life which the state cannot enter.

But the fainily itself is not beyond regulation in the public interest, as against a claim of religious liberty. And neither rights of religion nor rights of parenthood are beyond limitation.

133. Id. at 168 .

134. 410 U.S. at 154.

135. 197 U.S. 11 (1905). 
This pattern recurs in many bodily integrity cases. The individual's decision, although seemingly quite intimate on its face, is so bound up with a collective interest that it is considered to be within the public realm. Thus, for example, withdrawing blood from a person to provide evidence of excessive alcohol consumption does not intrude upon the zone of intimate decision. In Breithaupt v. $A b r a m^{136}$ the Court refused to exclude evidence so obtained, even though the person, previously involved in a fatal collision, was unconscious. In a later case, Schmerber v. California, ${ }^{137}$ the Court upheld a conviction based upon a blood sample taken while the defendant was awake and objecting. ${ }^{188}$ In his dissent Justice Douglas, relying on Griswold, injected privacy analysis: "No clearer invasion of this right of privacy can be imagined than forcible bloodletting of the kind involved here."139 It would have been possible for the Court to concede this point to Douglas while still upholding the procedure because of the compelling state interest in controlling the danger of drunk driving. ${ }^{140}$.It chose not to do so.

At first glance, what one chooses to ingest might seem to be a private decision. This is not necessarily the case. In a recent state case, Minnesota State Board of Health v. City of Brainerd, ${ }^{141}$ the Supreme Court of Minnesota affirmed a lower court ruling in favor of the state Board of Health's request for issuance of a writ of mandamus to compel the city to fluoridate the water supply. The city unsuccessfully contended that the people's constitutional right of privacy allowed the city to refuse fluoridation. ${ }^{142}$ At the other end of the privacy-of-

136, 352 U.S. 432 (1957).

137. 384 U.S. 757 (1966).

138. But see Rochin v. California, 342 U.S. 165 (1952).

139. 384 U.S. at 779.

140. Conversely, the danger of long hair seems minimal. Yet there is a deep division among the circuit courts on challenges to hair-length regulations. One court found that the decision about hair style was within the zone of privacy. Breen v. Kahl, 419 F.2d 1034 (7th Cir. 1969), cert. denied, 398 U.S. 937 (1970). Another struck down a hair-length regulation but specifically rejected privacy as grounds therefor. Richards v. Thurston, 424 F.2d 1281 (1st Cir. 1970). Others have upheld the regulations, scoffing at the notion that privacy was at issue in the cases. King v. Saddleback Jr. College Dist., 445 F.2d 932 (9th Cir. 1971), cert. denied, 404 U.S. 979 (1971); Jackson v. Dorrier, 424 F.2d 213 (6th Cir. 1970), cert. denied, 400 U.S. 850 (1970). Still others ignore privacy concerns altogether. Ferrell v. Dallas Ind. School Dist., 392 F.2d 697 (5th Cir. 1968). See also Olff v. East Side Union High School Dist., 404 U.S. 1042 (1972) (Douglas, J., dissenting from denial of petition for certiorari).

141. 241 N.W.2d 624 (Minn. 1976).

142. Id. at 631:

While the United States Supreme Court has never so held, the right of personal privacy could also extend to protect an individual's decision regarding what he will or will not ingest into his body. . . . Whether one's right to bodily integrity is designated a right of personal privacy or not, though, does not alter our conclusion that the right, like other constitutional rights, is not absolute. 
ingestion spectrum is Scott $v$. Plante, ${ }^{143}$ a Third Circuit case where a psychiatric hospital inmate alleged that he was forced to take psychotherapeutic substances against his will and contended that the allegation stated a cause of action under section 1983 of title 42 of the United States Code. The court of appeals had to decide whether the allegations stated a cause of action under the statute. It remanded, listing several possible constitutional deprivations on the face of the allegations, among then an invasion of the inmate's right to bodily privacy.

When a decision involving an individual's own body is inextricably intertwined with the welfare of other persons, that decision is not protected within the zone of intimate decision. Courts do not reach the issue whether the state has a coinpelling interest that justifies the governmental intervention because the individual's decisions are not included within the zone in the first place. Although some courts and coinmentators have spoken of interests in bodily privacy, most of the cases finding a right of bodily privacy involve intimate decisions regarding procreation. ${ }^{144}$

Probably the most basic decision involving one's body is the question of life or death. This is clearly an intimate or fundainental decision by any definition. Thus, the Supreme Court of New Jersey in In re Quinlan ${ }^{145}$ was able to ground its decision allowing a father to order physicians to withdraw life-support systems from his hopelessly infirm daughter on principles underlying privacy analysis:

Presumably [the right to privacy] is broad enough to encompass a patient's decision to decline medical treatment under certain circumstances, in much the same way as it is broad enough to encompass a woman's decision to terminate pregnancy under certain conditions. ...

...

... We think that the State's interest contra weakens and the individual's right to privacy grows as the degree of bodily imvasion increases and the prognosis dims. Ultimately there comes a point at which the individual's rights overcome the State interest. It is for that reason that we believe [the daughter's] choice, if she were competent to make it, would be vindicated by the law. ${ }^{148}$

\section{In-Home Possession}

A series of cases not involving either family, marriage, motherhood, procreation, bodily integrity, or child rearing adds one nore dimen-

143. 532 F.2d 939 (3d Cir. 1976).

144. See, e.g., Roe v. Wade, 410 U.S. 113 (1973.); Skinner v. Oklahoma ex rel. Williamson, 315 U.S. 535 (1942).

145. 355 A.2d 647 (N.J. 1976).

146. Id. at 663-64. 
sion to the contours of the zone of intimate decision. In Stanley $v$. Georgi $^{147}$ police officers entered Stanley's home with a search warrant, seeking evidence of bookmaking activities. Instead they found obscene film, and Stanley was convicted for possession of obscene matter in violation of Georgia law. The question was whether "a statute imposing criminal sanctions upon the mere [knowing] possession of obscene inatter"148 was constitutional. The state contended that there were certain types of material that the individual may not read or even possess. The Court disagreed, noting that the decision what to read or watch at home was left to the imdividual's own choice: "[Stanley] is asserting the right to read or observe what he pleases-the right to satisfy his intellectual and ennotional needs in the privacy of his own hoine."149 Moreover, the Court squarely held that the power of the state to regulate obscenity "simply does not extend to mere possession by the individual in the privacy of his own home."150 But emphasis was placed on the fact that the protected decision concerned events taking place exclusively withm the individual's home. ${ }^{151}$

Three cases decided in 1973 further reinforced the in-home limitation asserted in Stanley. United States v. 12200 Foot Reels $^{152}$ upheld a bar against private importation of obscene material for private use. Paris Adult Theatre I v. Slaton ${ }^{153}$ and United States v. Orito ${ }^{154}$ both held that no constitutionally protected zone of privacy followed a consumer of obscene materials outside the home. A person has no right to observe obscene material in a place of public accommodation.

If possession of obscene material at home is a decision to be left to the individual, other inaterial might also be possessed at home without state interference. This was the reasoning used by the Supreme Court of Alaska in Ravin v. State. ${ }^{155}$ The material there in question was inarijuana. In a well-reasoned opinion notable for its development of privacy doctrine, Chief Justice Rabinowitz, writing for the

147. 394 U.S. 557 (1969).

148. Id. at 559 .

149. Id. at 565 .

150. Id. at 568 .

151. Stanley illustrates the necessity of understanding the distinctions between the zones of privacy. The essence of the Stanley opinion is not that the state cannot enter a home and remove evidence in an obscenity arrest. That argument would be based on the zone of sanctuary. Protection in Stanley is provided by the zone of intimate decision. The holding is that the state cannot interfere in an individual's decision to have obscene material in the home. A careful distinction between the two zones was crucial to the defendant's case.

152. 413 U.S. 123 (1973).

153. 413 U.S. 49 (1973).

154. 413 U.S. 139 (1973).

155. 537 P.2d 494 (Alas. 1975). 
court, held that possession of marijuana by adults at home for personal use was constitutionally protected. The opinion discusses Stanley and its aftermath:

Privacy in the home is a fundamental right, under both the federal and Alaska constitutions. We do not mean by this that a person may do anything at anytime as long as the activity takes place within a person's home. There are two important limitations on this facet of the right to privacy. First, we agree with the Supreme Court of the United States, which has strictly limited the Stanley guarantee to possession for purely private, noncommercial use in the home. And secondly, we think this right must yield when it interferes in a serious nuanner with the health, safety, rights and privileges of others or with the public welfare. No one has an absolute right to do things in the privacy of his own lome which will affect hiniself or others adversely. Indeed, one aspect of a private matter is that it is private, that is, that it does not adversely affect persons beyond the actor, and hence is none of their business. When a nuatter does affect the public, directly or indirectly, it loses its wholly private character, and can be made to yield when an appropriate public need is demonstrated. ${ }^{156}$

The court did recognize that persons have no right to debilitate themselves to such a degree that they become public charges or otherwise burden the public welfare. "But we do not find that sucl a situation exists today regarding marijuana." 157 Althougl the case is not binding precedent on other jurisdictions, the opinion is very useful as a model of intimate decision analysis. ${ }^{138}$

\section{E. Sexual Activities of Consenting Adults in Private}

Griswold prompted speculation that the regulation of certain kinds of sexual activity might soon be held to be invasions of privacy. Clearly, decisions about what sexual acts one does in private with a consenting partner are imtimate. The Supreme Court lias held withm the past year, however, that sucli decisions are not protected by the zone of intimate decision.

After a three-judge court had held a Virginia sodomy statute constitutional both on its face and as applied to private, consensual homosexual acts in Doe v. Commonwealth's Attorney, ${ }^{159}$ the Supreme Court was presented with the question whether the statute violated the defendant's constitutional rights to privacy, due process, and equal protec-

156. Id. at 504 .

157. Id. at 509 .

158. See also People v. Sinclair, 387 Mich. 91, 133, 194 N.W.2d 878, 896 (1972) (T.G. Kavanagh, J., concurring). But cf. State v. Kantner, 53 Haw. 327, 493 P.2d 306 (1972); Commonwealth v. Leis, 355 Mass. 189, 243 N.E.2d 898 (1969).

159. 403 F. Supp. 1199 (E.D. Va. 1975). 
tion. The ruling by the lower court was affirmed without opinion. ${ }^{180}$ The reasoning of the lower court is thus the only guide in this area of privacy.

It is difficult to argue against the dissenting opinion of Judge Merhige in the lower court:

The Supreme Court has consistently held that the Due Process Clause of the Fourteenth Amendment protects the right of individuals to make personal choices, unfettered by arbitrary and purposeless restraints, in the private matters of marriage and procreation. I view those cases as standing for the principle that every individual has a right to be free from unwarranted governmental intrusion into one's decisions on private matters of intimate concern. A mature individual's choice of an adult sexual partner, in the privacy of his or her own home, would appear to me to be a decision of the utmost private and intimate concern. Private consensual sex acts between adults are matters, absent evidence that they are harmful, in which the state has no legitimate interest. ${ }^{101}$

Judge Merhige's opinion manifests a close congruence with the definition of the zone of intimate decision used in this Comment. Nonetheless, his was the mimority opinion, and the Supreme Court found the judgment of the majority more attractive.

The Doe majority mentioned only one privacy case, Griswold, and contended that its teaching was restricted to marriage, home, and family life-homosexuality was obviously no part of any of those. ${ }^{162}$ To show that the holding in Griswold did not bar state regulation of sexual promiscuity or inisconduct, the opimon dwelt on Justice Harlan's dissent in Poe v. Ullman, ${ }^{163}$ which Justice Goldberg had quoted approvingly in his concurrence in Griswold. ${ }^{164}$ Justice Harlan had expressed the view that homosexuality, adultery, fornication, and incest, even where privately practiced, were not immune from criminal prosecution. ${ }^{185}$

160. Doe v. Commonwealth's Att'y, 96 S. Ct. 1489 (19\%6).

161. 403 F. Supp. at 1203 (citations omitted). The same opinion explored prior intimate decision cases to support its reasoning:

Griswold . . . applied the right of privacy in sexual matters to the marital relationship. Eisenstadt, however, clearly demonstrates that the right to privacy in sexual relationships is not limited to the marital relationship. Both Roe and Eisenstadt cogently demonstrate that intinate personal decisions or private matters of substantial inportance to the well-being of the individuals involved are protected by the Due Process Clause. The right to select consenting adult sexual partners must be considered within this category. The exercise of that right, whether heterosexual or homosexual, should not be proscribed by state regulation absent compelling justification.

Id. at 1204.

162. Id. at 1202 .

163. 367 U.S. 497,553 (1961).

164. 381 U.S. 479, 498-99 (1965).

165. 367 U.S. at 552 . 
The Doe court obviously felt the same way and excluded the decision to commit sodomy from the zone of intimate decision.

Moreover, even if such a decision were arguably within the zone of protected interests, the state had a rational basis for interfering. "Fundamentally, the State action is simply directed to the suppression of crime, whether committed in public or in private."186 This view completely begs the question, however, since it ignores the essence of privacy claims-some acts simply cannot be crimes if they are private matters of substantial importance and are not performed in public. The court's view, on the other hand, was that state regulation is justified if the state shows that the conduct in question is likely to contribute to moral delinquency. In support of the state's fears on this point, it cited a recent case in that same district court ${ }^{167}$ where a married couple had invited a stranger to their home and committed various acts (defined as sodomy in Virginia) before a camera and the woman's 11- and 13-year-old daughters, the prints of the orgy ending up at school with the girls. This reasoning conflicts with the Stanley rationale that the potential threat of contamination outside the home caused by the protected obscene materials was not sufficiently weighty for the Court to interfere with Stanley's private in-home decision, particularly in view of the fact that the spreading of minority sexual proclivities outside the home is less likely than the spreading of obscene materials.

The conflict between Doe and Stanley illustrates two important characteristics of privacy analysis. First, more than one criterion has been developed to determine whether a particular decision merits protection as part of the intimate decision zone. If a personal decision is widely accepted as a "private matter of intimate concern"168 there is good reason to protect it. Justices Harlan and Blackmun, however, used a different criterion: whether the right to make the decision was "fundamental"169 or "implicit in the concept of ordered liberty."170 The decision to commit sodomy may well be a private matter of intimate concern; but it is much harder to argue that it is a decision implicit in the concept of ordered liberty. Many courts, including the present Supreme Court, are more likely to be impressed by an appeal to the latter criterion.

The second point is more subliminal. The attachment of the labels "intimate," "fundamental," or "implicit in the concept of ordered

166. 403 F. Supp. at 1202.

167. Lovisi v. Slayton, 363 F. Supp. 620 (E.D. Va. 1973).

168. Doe v. Commonwealth's Att'y, 403 F. Supp. 1199, 1203 (E.D. Va. 1975)

(Mehrige, J., dissenting).

169. Roe v. Wade, 410 U.S. 113, 152 (1973).

170. Id. See also Griswold v. Connecticut, 381 U.S. 479, 500 (1965). 
liberty" to any given decision does not depend entirely upon judgments about the nature of the particular intimate decision. Courts will attach those labels to initiate a privacy inquiry only where all of the possible outcomes of that personal decision are at least marginally acceptable. If an individual's choice of conduct might include a personal decision that the court perceives as unacceptable considering the prevailing mores, the court may simply find that the decision is not "intimate" enough to be protected. If society's standards of acceptable behavior change, the same decision may suddenly be accorded protected status. This explaims to a certain degree the timing of pro-privacy decisions in Griswold, Roe, Quinlan, and Ravin. It also clarifies the anti-privacy holdings in Doe v. Commonwealth's Attorney and Belle Terre, where the decisions in question were certainly private and imtimate (as dissents in both cases argued ${ }^{171}$ ), but where the behavior that freedom of intimate decision might bring about was clearly unacceptable to the courts.

VI

\section{A COMPENDIUM of PrIVACY Protection For REPOSE, SANCTUARY, AND INTIMATE DECISION}

The zone of repose stands in the inost precarious position of the three zones, lacking any type of constitutional protection. This wcakness is a consequence of the fact that most, if not all, repose cases $\mathrm{m}$ volve conflicts between private parties. The Constitution himits the conduct of the state. Whatever restrictions the Constitution places upon the ability of government to bother a person, it has little to say about a conflict between citizens. On the other hand, when the government does become iniplicated in some way with the bothersome activitysuch as the mailings in Rowan and the state-operated transit lines in Pollack and Lehman-the Court has been very sensitive to the individual's right of repose.

Although the Constitution normally will not protect the zone of repose, it will often license imterference with repose. Since only legislation will protect the zone of repose, whatever constraints the Constitution places upon protecting legislation may be viewed as tacit approval of the invasion. The first anendment's guarantees recognize to a certain extent a citizen's right to be bothersome. ${ }^{172}$ The courts are then left with the task of determining when statutes have gone too far in curtailing the invasion of repose. Justice Harlan identified three factors that can resolve the issue whether: the state has exceeded its powers in attempting to protect the sensibilities of its citizens:

171. See text accompanying notes 125 \& 161 supra.

172. See generally Haiman, Speech v. Privacy: Is There a Right Not to Be Spoken to?, 67 Nw. U.L. ReV. 153 (1972). 
The ability of government, consonant with the Constitution, to shut off discourse solely to protect others from hearing it is, in other words, dependent upon a showing that substantial privacy interests are being invaded in an essentially intolerable inanner. Any broader view of this authority would effectively empower a Inajority to silence dissidents simply as a inatter of personal predilections..$^{173}$

These three factors constitute a test that requires a proponent of privacy to show much more than the mere existence of a "substantial privacy interest." The Court also demands a showing that the privacy interest is "invaded" and that the mvasion is "essentially intolerable." Thus, a person at home obviously enjoys substantial privacy rights, but once on the streets, that same person's right to privacy may no longer be substantial. ${ }^{174}$ It is unclear, however, whether the Court's concern for "captives" is because of the captive's substantial privacy interest or because any invasion of even a slight privacy interest would be essentially intolerable. At any rate, weight is shifted toward the privacy side of the fulcrum if a person is a captive.

"Essentially intolerable" is a test of even less distinct outlines. There are, however, two identifiable components of importance. If the level of sensory impact is high (for example, loud and raucous sound), the Court may find the invasion intolerable. This outcome comports with common notions of privacy. But the Court also scrutinizes the informational content of the invasion to aid in deciding intolerability. Sexually provocative mail may be essentially intolerable and thus barred from entering the zone of repose. It is questionable whether political advertising could similarly be barred. Here the Court arguably is exceeding the proper scope of inquiry. Although the distinction between what is said and how it is said has always proven difficult to articulate, privacy in a pluralistic society is better served if the law concentrates on the mode rather than on the content of communication in determining whether it is essentially intolerable.

A similar balancing procedure is required in many zone of sanctuary cases. Whenever one private person attempts to appropriate information about another and turn it to private use, the zone is penetrated. In such cases, just as with the zone of repose, privacy lacks constitutional protection. Moreover, the invasion may be supported by the Constitution's prohibitions against laws abridging freedoin of the press. Statutes and common law rules protecting sanctuary must not exeed the constitutional limits thus imposed.

173. 403 U.S. at 21.

174. "[T]his Court has recognized that government may properly act in inany situations to prohibit intrusion into the privacy of the home of unwelcome views and ideas which cannot be totally banned from the public dialogue . . . " Id. 
But here the similarity between sanctuary and repose ceases. First, whereas the Court should and generally does avoid deciding a privacy of repose issue solely on the basis of the informational content of the penetration, the informational content of an extraction from the zone of sanctuary is precisely what most concerns the Court. If an event is newsworthy or a matter of public record, no legislation will be permitted to keep it secret. There is little concern about the intolerability of the mode of publication or the weight of the interest of the exposed party in keeping secret the exposure. If a fact is true and newsworthy, it cannot be suppressed. The analysis used in repose cases, slippery and unstable as it may be, makes the crude test in sanctuary cases between private persons look harsh and cold in comparison. The newsworthiness test makes no distinction between parties who are newsworthy because of great misfortune and those who are newsworthy because of culpable or knowledgeable conduct. It draws no line between the name of a rape victim or arrestee that is public only imsofar as it is part of a rarely read police or court file and a name publicized on a television news broadcast or publicly distributed handbill.

The test apphed in repose cases tilts heavily in favor of speech interests, yet attempts to make subtle distinctions between situations whenever speech and repose collide. A similar test, with a similar preference favoring freedom of the press, should be developed to remforce the zone of sanctuary in cases of conflicting interests between private parties.

When the zone of sanctuary is invaded by the state, the Constitution can help to define and reinforce its boundaries. Extraction of information by the state is restricted by the fourth amendment. The Court has concentrated on determining whether a "seizure" of information has been unreasonable. To aid in this determination, the Court employs a unique combination of subjective and objective tests. First, the Court asks whether the person in question actually expected privacy in such a situation. Even if the answer is yes, the extraction may still be reasonable if the Court determines that society would find the expectation of privacy unreasonable. The first question appears to have no function and inerely muddles the analysis. If a person makes some efforts to gain privacy, the actions manifest an expectation of privacy. Then the quesion is whether society acquiesces in this belief. But if a person makes no efforts to gam some measure of privacy, it is a foregone conclusion that society will consider it unreasonable for that person to have any privacy expeetations. It would be helpful to eliminate such a complicated and abstract facade. The more direct approach is simply to imquire whether or not society is willing to permit privacy of sanctuary to be subsumed under the fourth amendment's guarantees 
of personal security given the facts of the situation. Using this approach, the reasonable expectations standard retains its flexibility without losing its force.

No single amendment protects the zone of intimate decision. Scholars and jurists have sought to find protection in at least five amendments. ${ }^{175}$ Despite the debate as to the source of the protection, one thing is clear: the zone of intimate decision draws its protection froin the Constitution alone. No legislative enactment is required to reinforce its boundaries.

The analysis required of courts faced with intimate decision claims revolves around two questions: Is the decision to be protected an intimate decision? If so, does the state have a compelling interest in interfering with that decision? The second question is familiar to jurists; the analytical framework developed in equal protection analysis serves as a guide in the privacy context. But the first question is unique to privacy conflicts.

Courts have einployed terms such as "intimate," "fundamental," and "implicit in the concept of ordered liberty" to aid thein in determining whether the zone of intimate decision should protect a particular assertion of individual autonony. Yet the clearest exposition of the question perhaps comes from the Supreine Court of Alaska: "[O]ne aspect of a private inatter is that it is private, that is, that it does not adversely affect persons beyond the actor, and hence is none of their business."178 The proposed "none-of-their-business" test helps to clarify past opinions and to predict the nature of future applications of the zone of intimate decision. Obviously vaccinations, fluoridation, and highway safety are subjects that involve persons other than the individual, and courts have so held. Just as obviously, child abuse and wifebeating in the privacy of one's own home constitute conduct that is someone else's business. The majority in Doe v. Commonwealth's Attorney felt that the sexual activity of consenting adults there in question partook of the same quality, and demonstrated their belief with a story of another situation involving atypical sexual behavior that had contaninated a local school. Although it is possible to differ with the Doe majority, the most persuasive argument open to privacy proponents in such cases is a clear deinonstration that the intimate decisions in question are highly unlikely to adversely affect anyone other than the persons making the decision, and thus that it is none of anyone else's business. Such an argument inay more often prevail than one concentrating on the abstract and historical standards of "fundamentalness" and "implicit in the concept of ordered liberty."

175. See note 102 supra.

176. Ravin v. State, 537 P.2d 494, 504 (Alas. 1975). 


\section{CONCLUSION}

Anyone, whether litigant or judge, confronted with an issue that involves privacy, must resist the temptation to view the newly articulated right to privacy as a monohth. The right to be let alone closely corresponds to the spacing mechanisms that regulate behavior within the animal world. Just as there are many different spacing mechanisms, each with a different function, there are at least three different legally cognizable zones of privacy that surround individuals. Great care is necessary in determining which zone is at issue in any given case, smce the mode of analysis, type of proof, standards, and source of protection vary between the zones.

One of the most vital distinctions is whether the Constitution can be invoked to support a claimant's plea to be let alone. Griswold establislied-and its progeny reinforced-the right of privacy to make certain intimate and intensely personal decisions without state interference. The fourth ainendment protects the privacy of sanctuary in certain specific situations where very tangible material and very tangible premises are at issue. Beyond those situations, the zone of sanctuary is an uncertain shield against the state's extraction of data for its own purposes or against publication of private facts by the press. The zone of repose has never received any constitutional protection.

The extent of constitutional protection is not the only distinction between the types of privacy. Each zone protects a unique type of human transaction. Repose inaintains the actor's peace; sanctuary allows an individual to keep some things private, and intimate decision grants the freedoin to act in an autonomous fashion. Whenever a generalized claim to privacy is put forward without distinguishing carefully between the transactional types, parties and courts alike may become hopelessly muddled in obscure claims. ${ }^{177}$ The clear standards that appear within each zone are frequently ignored by claimants anxious to retain some aspect of their personal liberty ${ }^{178}$ and by courts impatient with the indiscriminate invocation of privacy. ${ }^{178}$

177. Certainly one of the bases for Justice Rehnquist's curt dismissal of the claim to privacy in Paul v. Davis, 96 S. Ct. 1155, 1166 (1976), quoted in the text accompanying note 100 supra, is that the claim appeared to be grouncled upon Griswold and the zone of intimate decision. The transaction complained of was rather one that, if it intruded upon any zone, intruded upon the zone of sanctuary.

178. See Fitzgerald v. Porter Mernorial Hosp., 523 F.2d 716, 721 (7th Cir. 1975), cert. denied, 96 S. Ct. 1518 (1976): "We hold that the so-called right of marital privacy does not include the right of either spouse to have the husband present in the delivery room of a public hospital . . . ."

179. See, e.g., Doe v. Commonwealth's Att'y, 96 S. Ct. 1489 (1976); Richards v. Thurston, 424 F.2d 1281, 1283 (1st Cir. 1970). 
Finally, it should be recognized that the right of privacy is a continually evolving right. This Comment has attempted to show what findings of fact will lead to the legal conclusion that a person has a right to privacy. Yet the same findings of fact may lead to different conclusions of law as time passes and society's ideas change about how much privacy is reasonable and what kinds of decisions are best left to individual choice. Future hitigants must look to such changes im community concerns and national acceptance of ideas as harbingers of corresponding changes in the contours of the zones of privacy.

Gary L. Bostwick*

* B.S. 1963, Northwestern University; M.P.P. 1976, University of California, Berkeley; third-year student, Boalt Hall School of Law. 